\title{
PREDICTION OF TOMATO EARLY BLIGHT DISEASE UNDER CLIMATE CHANGE CONDITIONS IN EGYPT
}

\author{
Hassan $^{1 *}$ H.A., Abolmaaty ${ }^{1}$ S.M., Afaf Z.A. Elmenisy ${ }^{2}$ and Abd El-Ghafar ${ }^{2}$ N.Y. \\ 1- Central Lab. Agric. Climate, ARC, Giza, Egypt \\ 2- Plant Pathology Dept., Fac. of Agric., Ain Shams Univ., P.O. Box 68, Hadayek Shobra11241, \\ Cairo, Egypt
}

\section{*Corresponding author: Hassan clac@yahoo.com}

Received 21 August, 2019

Accepted 4 September, 2019

\section{ABSTRACT}

Early blight caused by Alternaria solani (Ell. and Mart.) is one of the most important diseases, which caused considerable loss in tomato yield and quality under Egyptian conditions. The research aimed to study the relationship between climate change and disease severity for prediction in future seasons. Disease severity was recorded for three growing seasons i.e. summer (May. Aug), autumn (Jul. - Oct) and winter (Nov. - Mar.), at three governorates (Behira, Ismailia, and Assuit). Severity of early blight disease on tomato has been predicted by regression estimated accumulative disease severity values during (2007/2008) (2015/2016) season and average max and min temperature and humidity through these seasons. Prediction of disease has been formed as $Y=$ $b 0+b 1 \times 1+b 2 \times 2+\ldots \ldots . .$. bqxq. Three models were created to describe the severity disease by multiple regressions (MINITAB® program). The highest value of early blight disease was recorded through season (2017/2018), while the lowest value was recorded during season (2016/2017). Also, highly disease severity was estimated during summer period compared with autumn and winter growing periods, however, the least severity was estimated through winter growing period and moderate severity estimated in the autumn growing period. Influence of environmental conditions on the severity of early blight disease during seasons $(2007 / 2008)$ - (2015/2016), in Behira governorate, the high disease severity was showed in season (2010-2011), and the lowest disease was in season (2012-2013), but in Ismailia governorate, highest disease severity was estimated in season
(2010-2011) and low in season (2013-2014), but in Assuit governorate, the highest value of disease was in season( 2010-2011), and the lowest value was in season (2013-2014). For Forecasting, significantly differences among between disease severity through (2020/2030), (2030/2040) and (2040/2050) seasons compared with (2008/2018) seasons and relation with climate change in tested governorates. Severity of tomato early blight disease may increase from $11.8 \%$ to 15.4 during (2008/2018) seasons to (2040/2050) seasons at Behira governorate, from $18.8 \%$ during (2008/2018) seasons to $36.3 \%$ (2040/2050) seasons at Ismailia governorate and $18.8 \%$ during (2008/2018) seasons to $40.4 \%$ (2040/2050) seasons at Assuit governorate with slight change in maximum or minimum temperatures and percentage of relative humidity.

Keywords: Tomato Early blight disease, Alternaria solani, Climate change, Forecasting, GIS.

\section{INTRODUCTION}

Tomatoes (Solanum lycopersicum L., syn. Lycopersicon esculentum Mill.) is one of the most popular and widely grown vegetables in the world. It occupied the second rank in importance after potato in many countries (Prajapati et al 2014). It considers an important cash and industrial crop in many parts of the world (Ayandiji and Omidiji, 2011). Early blight disease of tomato caused by the fungus Alternaria solaniis one of the most common foliar diseases of tomatoes, which damages the leaves, stalks, stems and fruits causing severe destruction of the aerial part and reduction of the size and number of fruits, resulting heavy 
losses in yield up to $79 \%$ (Sherf and MacNab, 1986; Gwary and Nahunnaro, 1998). The Alternaria fungus can cause the disease on all parts of the plant (leaf blight, stem collar rot, and fruit lesions) and result in severe damage during all stages of plant development (Abada et al 2008). Climate factors that influence the growth, spread and survival of crop diseases including temperature, precipitation humidity, dew, radiation, wind speed, circulation patterns and the occurrence of extreme events. Higher temperature and humidity and greater precipitation result in the spread of plant diseases, as wet vegetation promotes the germination of spores and the proliferation of fungi and bacteria and influence the life cycle of soil nematodes (Rosenzweig et al 2000). Environmental condition is a complex term that includes many factors, which must be behind a minimum threshold for the disease to occur. A change in one environmental factor may alter the effect of other environmental factors on diseases development (Abdel-Hak et al 1966). The relationship between weather and plant disease are routinely used for forecasting and managing epidemics and disease severity over the number of years can fluctuate according to climatic variation (Scherm and Yang, 1995). There was a positive relationship between development and severity of wheat rust diseases and location, date or mean temperatures, at eight governorates, on growing seasons 2005s, under Egyptian conditions, where the severity of leaf rust disease, on growing seasons 2050s and 2005s were (Abolmaaty, 2006). The present work aimed to study the influence of climate change on the severity of tomato early blight disease and Prediction of disease severity under future condition.

\section{MATERIALS AND METHODS}

\section{Survey of tomato early blight disease}

This study was conducted at three governorates i.e. Behira, Ismailia in lower Egypt and Assuit middle Egypt, during growing seasons (2016/2017)-(2017/2018), where three locations were selected each governorate at least 25 feddan per location for survey a tomato early blight disease. Plant samples based on visual symptoms of the disease were drawn from each field at random. Sampling for smaller units $\left(25^{\mathrm{m} 2}\right)$ was done along the diagonals of the fields at regular intervals each month of each growing season. Selected units were drawn following a zigzag pattern and ten plants per unit were selected to estimate the severity of the disease (Syed et al 2016). Disease severity was recorded after 60 days form sowing date for three consecutive growing seasons i.e. summer (May. - Aug), autumn (Jul. - Oct) and winter (Nov. Mar.). The severity of disease was assessed on 100 randomly selected plants / 10 smaller units /field. Disease severity was estimated according to a disease rating scale from $0-5$, where $0=$ no visible symptoms apparent, $1=\mathrm{A}$ few minute lesions to about $10 \%$ of the total leaf area is blighted and usually confined to the 2 bottom leaves, $2=$ Leaves on about $25 \%$ of the total plant area are infected , $3=$ Leaves on about $50 \%$ of the total plant area are infected, 4 = Leaves on about $75 \%$ of the total plant area are infected and $5=$ Leaves on the whole plant are blighted and plant is dead (Sethumadhava et al 2016). The formulae in calculating the disease severity follow:

Percentage of disease severity $($ PDS $)=\frac{\text { Number of Individual Raitngs }}{\text { Number of Plants Assesed }} \times \frac{100}{\text { Maximum Scale }}$

Influence of Environmental conditions on Tomato Early Blight disease

Meteorological data were recorded through the growing seasons (2007/2008) - (2015/2016). These data were obtained from the Central Laboratory for Agricultural Climate (CLAC). The data consist of average temperature (daily maximum and minimum temperature) and relative humidity (daily maximum and minimum $\mathrm{RH} \%$ ). The diseases

severity was estimated as the percentage of infected fields. The data of disease severity were obtained from the Central Administration of Pest Control, Ministry of Agriculture, Egypt (unpublished data). The effect of each factor separately was obtained by applying simple correlation formula ( $r$ ) and the regression coefficients (b). The combined effects of these factors were obtained by applying multipliers formula and expressed as percentage of explained variance. (E.V) according to Hassan (2016).

Effect of expected future climate change on incidence of early blight of tomato

The future climate data (2030s to 2050s) has been obtained from the downscaling process on global climate model (ECHAM6) of scenario Representative Concentration Pathways RCP 4.5 by a horizontal resolution $50 \mathrm{~km}$ using regional climate model (RegCM 4) (Khalil et al 2016). The severity 
of tomato early blight disease during the period 2030s and 2050s in Egypt were estimated using disease severity data during 2008 - 2018 seasons, using the Statistical programs for windows and MINITAB® program, where the climate data in the future 2030 season to 2050 according to Abolmaaty (2006). Using geographical information system (GIS) generated base classification maps of the research area according to programs (ArcGIS $\left.{ }^{\circledR}\right)$ for windows.

\section{RESULTS AND DISCUSSION}

\section{Survey of tomato early blight disease}

Several fields of tomato plant, at three different Governorates (Behira, Ismailia, and Assuit) were surveyed for incidence of early blight during seasons (2016/2017)-(2017/20018) three growing seasons i.e. summer (May. - Aug), autumn (Jul. Oct) and winter (Nov. - Mar.). Data in Fig. (1) show that, in Behira governorate, the mean disease severity value of disease was ranged from $25.7 \%$ to $6.3 \%$. The highest disease severity value $(25.7 \%)$ was recorded in autumn growing period (2016-2017). The minimum disease severity (6.3 $\%)$ was recorded in autumn growing period (20172018). Finally, the highest value of disease was appeared through season (2016/2017), while the lowest value was estimated through growing season (2017/2018).

While, in Ismailia governorate, mean disease severity was ranged from $27.9 \%$ to $1.6 \%$. Highest disease value (27.9\%) was recorded in autumn growing period (2017-2018), but, minimum disease was $(1.6 \%)$ recorded in autumn growing period (2016-2017). Generally, the highest severity of disease was recorded during season (2017/2018) and the lowest value was recorded during season (2016/2017).

In Assuit governorate, the mean disease severity was ranged from $13.1 \%$ to $5.0 \%$. The highest disease $(13.1 \%)$ recorded in autumn growing period (2017-2018), but the minimum disease (4.8\%) recorded in winter growing period (2016-2017). Also, the highest value of disease was appeared through season (2017/2018), and the lowest value recorded during season (2016/2017). Meanwhile, the high disease severity was recorded summer period, while, the least and moderate severity were recorded in the winter and autumn growing period, respectively.

\section{Influence of environmental conditions on toma- to early blight disease}

Results in Fig. (2) reveal that mean severity of disease in Behira governorate was $18.8 \%$, but the highest disease severity $(25.7 \%)$ was recorded in season (2010-2011), Where the mean maximum and minimum temperature was $29.4^{\circ} \mathrm{C}$ and $16.3^{\circ} \mathrm{C}$ respectively and the mean percentage of relative humidity was $52.6 \%$. While the lowest disease $(14.0 \%)$ was detected in season 2012-2013, where the mean maximum and minimum temperature was $29.4{ }^{\circ} \mathrm{C}, 16.1{ }^{\circ} \mathrm{C}$, respectively and the mean percentage of relative humidity was $48.6 \%$. The mean severity of disease in Ismailia governorate was $14.6 \%$, but the highest disease severity (24.6\%) was estimated in season (2010-2011), where mean maximum and minimum temperature was $29.4{ }^{\circ} \mathrm{C}$ and $16.6{ }^{\circ} \mathrm{C}$, respectively and mean percentage of relative humidity was $55.0 \%$. Meanwhile, the lowest disease $(10.1 \%)$ was recorded in season (2013-2014), where the mean maximum and minimum temperature was $28.7{ }^{\circ} \mathrm{C}$ and 16.1 ${ }^{\circ} \mathrm{C}$, respectively and the mean percentage of relative humidity was $53.7 \%$. Also, the mean prevalence value of disease in Assuit governorate were $26.9 \%$, but the highest value of disease $(30.7 \%)$ was in season (2010-2011), where the mean maximum and minimum temperature was $32.1^{\circ} \mathrm{C}$, $16.6^{\circ} \mathrm{C}$, respectively and the mean percentage of relative humidity was $52.6 \%$. While, the lowest value $(22.7 \%)$ was recorded in season (2013-2014), where mean maximum and minimum temperature was $31.0^{\circ} \mathrm{C}$ and $15.91^{\circ} \mathrm{C}$, respectively and mean percentage of relative humidity was $50.4 \%$. Finally, the highest severity of disease was estimated at Assuit governorate (26.9\%) compared with Behira and Ismailia governorates, where the mean maximum and minimum temperature was $31.2^{\circ} \mathrm{C}$ and $15.9^{\circ} \mathrm{C}$, respectively and mean percentage of relative humidity was $50.8 \%$.

Statistical analysis for the effects of mean max and min temperature and relative humidity on early blight disease, during 2007/2008 to 2015/2016 season at Behira, Ismailia, and Assiut governorates are shown in Table (1). The results show that the max temperature, min temperature, and relative humidity had an insignificant negative effect whereas " $r$ " value was $-0.011,-0.32$ and -0.30 , respectively at Behira governate. The results also 


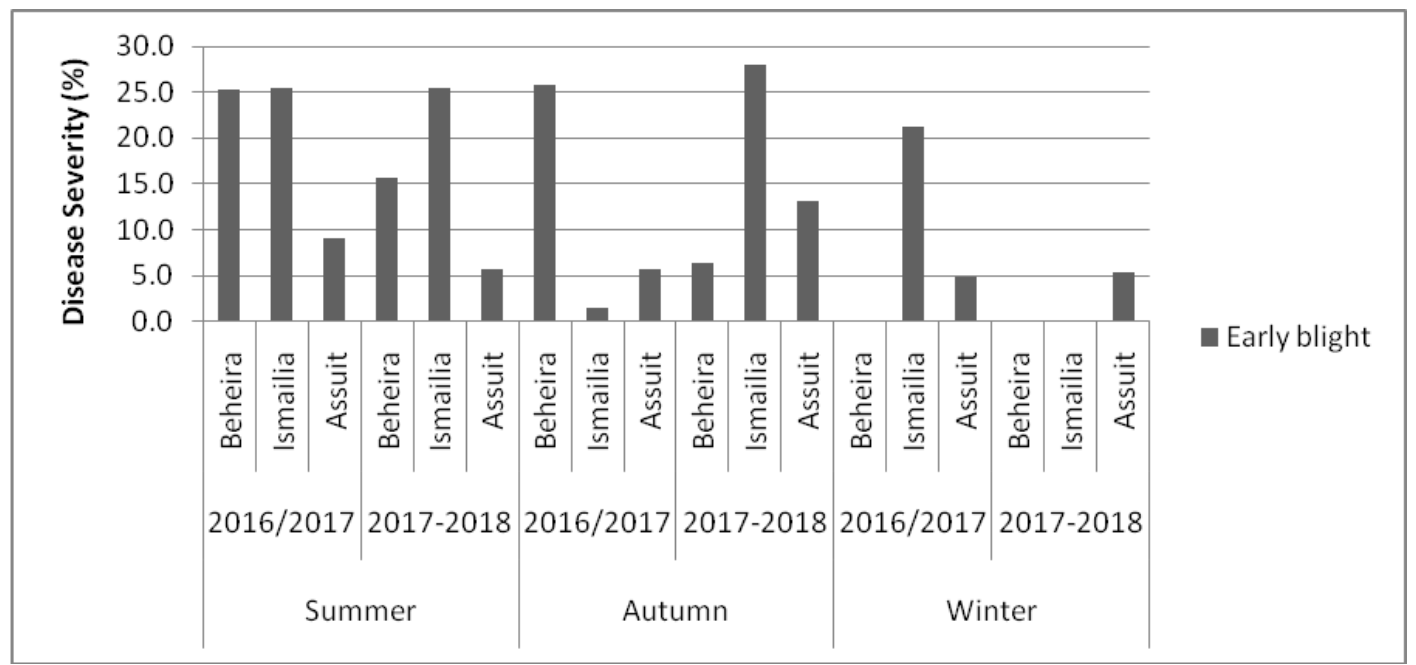

Fig. 1. Severity of tomato early blight disease, during (2016/2017-2017/20018) seasons, through growing periods (summer, autumn and winter) at Behira, Ismailia and Assuit governorates

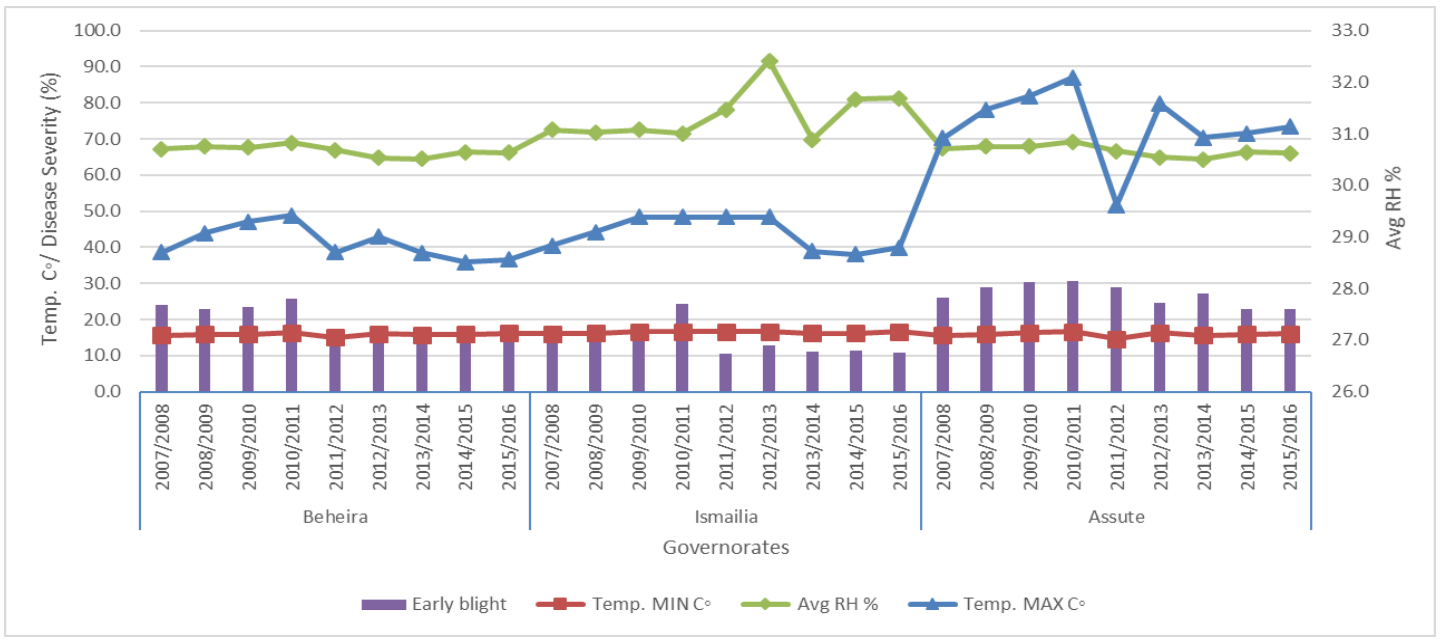

Fig. 2. Relationship between environmental conditions and severity of tomato early blight disease, during $(2007 / 2008)$ to $(2015 / 2016)$ seasons at Behira, Ismailia and Assuit governorates, under filed conditions

show that the max temperature and min temperature had an insignificant positive effect whereas " $r$ " value was 0.31 and 0.36 , respectively. Relative humidity insignificant negative effect whereas " $r$ " value was -0.41 at Ismailia governate. In Assuit governate, the max temperature and min temperature had a highly significant negative effect whereas " $r$ " value was -0.52 and -0.69 , respectively and relative humidity had a highly significant positive effect whereas " $r$ " value was 0.96 . The percentages of explained variances (E.V) for the selected ecological factors at seasons were $45 \%, 44 \%$ and $68 \%$ on the severity of disease, during (2007/2008) to $(2015 / 2016)$ seasons, respectively. "F" values were $1.90,1.85$ and $68.58^{* * *}$, respectively.

Climate change can have positive, negative or neutral impact on individual path systems because of the specific nature of the interaction of host and pathogen. Also, climate change can influence the geographical and growth of plant species around the world (Coakley et al 1999), computable with study data. (Nicholls., 1997) analyzed historical trends in Australian wheat yield and found that recent climate changes are responsible for as much as 30 to $50 \%$ of the variation explained by an increase in minimum temperature. In New Zea- 
land (Presidge and Pottinger, 1990) concluded that disease problems in the kiwifruit and pome fruit industries would probably amplify by increases in temperature and precipitation. In contrast, the impact on the vegetable industry should be minimal because this industry is annual and intensive in nature and management changes required to mitigate climate change impacts may be mode more easily. A climate change has the potential to modify host physiology and resistance and to modify host and resistance and to alter stages and rates of development of the pathogen. The most likely impact could be shift in the geographical of the host and the pathogen, which may be could changes in the physiology of host-pathogen interactions and changes in crop loss. Change may occurs in the type, amount and relative importance of pathogens and affect the spectrum of diseases affecting a particular crop. This would be more pronounced for pathogens with alternate hosts
(Coakley et al 1999). Increase in temperature can modify host physiological and resistance arise in temperature above $20 \stackrel{\circ}{c}$ can inactivate temperature - sensitive resistance to stem rust in oat cultivars with Pg3 and Pg4 genes (Martens et al 1967). In contrast, lignifications of cell walls increased in forage species at higher temperatures (Wilson et al 1991) to enhance resistance to fungal pathogens (Strange 1993). The disease may develop if plants are stressed in a warmer climate. High temperatures may increase the damage caused by the disease such as scleroderris canker lodge pole pine (Karlman et al 1994 and Lonsdale and Gibbs, 1996). Suggest that severe weather events are making an important contribution to the emergence of plant diseases in new locations. There is a greater likelihood that invasive disease can become established as. Climate change can also allow some plants and pathogens to survive outside their historic ranges (Harvell et al 2002).

Table 1. Simple correlation and partial regression values of the climatic changes and severity of early bight disease corresponding percentage of explained variance in Tomato plant fields at Beheira, Ismailia and Assuit governorates, during (2007/2008) - (2015/2016) growing seasons

\begin{tabular}{|c|c|c|c|c|c|c|}
\hline \multirow{3}{*}{\begin{tabular}{|c|} 
Beheira \\
Early blight \\
Tested
\end{tabular}} & \multicolumn{6}{|c|}{ Seasons from 2007/2008to 2015/2016 } \\
\hline & \multirow{2}{*}{\multicolumn{2}{|c|}{$\begin{array}{c}\text { Simple } \\
\text { Correlation }\end{array}$}} & \multirow{2}{*}{\multicolumn{3}{|c|}{$\begin{array}{c}\text { Partial } \\
\text { Regression }\end{array}$}} & \multirow{3}{*}{$\begin{array}{c}\% \\
\text { E.V. }\end{array}$} \\
\hline & & & & & & \\
\hline \multirow{4}{*}{\begin{tabular}{|c|} 
factors \\
Temp. MAX ${ }^{\circ} \mathbf{C}$ \\
Temp. MIN C $。$ \\
Avg RH \% \\
\end{tabular}} & $r$ & $\mathbf{P}$ & b & S.E. & $\mathbf{P}$ & \\
\hline & -0.011 & 0.99 & 8.71 & 4.17 & 0.075 & \multirow{4}{*}{$45 \%$} \\
\hline & -0.3208 & 0.35 & -12.18 & 6.25 & 0.092 & \\
\hline & -0.3008 & 0.37 & 0.29 & 0.39 & 0.486 & \\
\hline \multirow{2}{*}{\multicolumn{7}{|c|}{$F=1.90$}} \\
\hline & & & & & & \\
\hline \multirow{2}{*}{$\begin{array}{c}\text { Early blight } \\
\text { Tested }\end{array}$} & \multicolumn{2}{|c|}{ Simple } & \multicolumn{3}{|c|}{ Partial } & \multirow{2}{*}{$\%$} \\
\hline & \multicolumn{2}{|c|}{ Correlation } & \multicolumn{3}{|c|}{ Regression } & \\
\hline factors & $\mathbf{r}$ & $\mathbf{P}$ & b & S.E. & $\mathbf{P}$ & E.V. \\
\hline Temp. $\mathbf{M A X}{ }^{\circ} \mathbf{C}$ & 0.31 & 0.36 & 8.66 & 6.19 & 0.2 & \multirow{4}{*}{$44 \%$} \\
\hline Temp. MIN C。 & 0.36 & 0.63 & -5.42 & 5.77 & 0.37 & \\
\hline Avg RH \% & -0.41 & 0.21 & -0.30 & 0.2 & 0.182 & \\
\hline \multicolumn{6}{|c|}{$\mathrm{F}=1.85$} & \\
\hline \multirow{4}{*}{$\begin{array}{c}\text { Assute } \\
\text { Early blight } \\
\text { Tested } \\
\text { factors }\end{array}$} & \multicolumn{5}{|c|}{ Seasons from 2007/2008to 2015/2016 } & \multirow{3}{*}{$\%$} \\
\hline & & & \multicolumn{3}{|c|}{ Partial } & \\
\hline & \multicolumn{2}{|c|}{ Correlation } & \multicolumn{3}{|c|}{ Regression } & \\
\hline & $\mathbf{r}$ & $\mathbf{P}$ & $\mathbf{b}$ & S.E. & $\mathbf{P}$ & E.V. \\
\hline Temp. MAX ${ }^{\circ} \mathbf{C}$ & -0.52 & 0.098 & 8.2 & 3.24 & 0.039 & \multirow{4}{*}{$68 \%$} \\
\hline Temp. MIN C。 & -0.69 & 0.018 & -9.19 & 3.72 & 0.043 & \\
\hline Avg RH \% & 0.96 & 0.0001 & -1.72 & 0.16 & 0.0003 & \\
\hline \multicolumn{6}{|c|}{$\mathrm{F}=68.58^{* * *}$} & \\
\hline
\end{tabular}




\section{Effect of expected future climate change on tomato early blight disease}

This study was carried out to figure out the influence of climate change on severity of early blight disease of tomato, during (2020/2030), (2030/2040) and (2040/2050) seasons, under Egyptian condition, at three governorates, using the multiple equation regression analysis (MINITABB). The severity of disease has been predicted by regression estimated disease severity versus the accumulative disease's severity values during (2007/2008) to (2015/2016) seasons and average max and min temperature and humidity through the both seasons. Prediction of disease has been formed as $Y=b_{0}+b_{1} x_{1}+b_{2} X_{2}+\ldots \ldots \ldots . . . b_{q} x_{q}$ (Fahim, 2002). Three models were created to describe the severity disease by multiple regressions (MINITAB® program, 1995). Regression between disease severity values at during seasons from $2007 / 2008$ to $2015 / 2016$ and average max an min temperature and humidity during the seasons resulted in the following relationship:
(1) Beheira $y=-236.1+6.03 \times 1-3.59 \times 2+$ $2.723 \times 3 \quad \mathrm{R}^{2}=93.1 \%$
(2) Ismailia $y=-289.6+13.25 \times 1-2.84 \times 2-$ $0.389 \times 3 \quad \mathrm{R}^{2}=82.4 \%$
(3) Assuit $\quad y=186.8-12.96 \times 1-14.82 \times 2+$$$
0.896 \times 3 \quad R^{2}=82.5 \%
$$

Where:

$\mathrm{Y}=$ prediction of disease severity (\%)

$\mathrm{X} 1=$ average max temperature $\left({ }^{\circ} \mathrm{C}\right)$

$\mathrm{X} 2=$ average $\min$ temperature $\left({ }^{\circ} \mathrm{C}\right)$

X3 =average humidity (\%).

Model 1, 2 and 3 could Lower Egypt and Upper Egypt, respectively. Formal tests have been used to evaluate statistical assumption. The coefficient of determination $R^{2}$ were ranged between 82.4 and 93.1 for climate change scenarios for Behira, Ismailia and Assuit Governorates were assessed according to future conditions derived from the downscaling process on global climate model (ECHAM6) of scenario Representative Concentration Pathways RCP 4.5 by a horizontal resolution
$50 \mathrm{~km}$ using regional climate model (RegCM 4) and these relation with severity of early blight disease of tomato.Generated base classification maps of the research area according to program (ArcGIS®) for windows.

Data presented in Fig. (3) showed that severity of tomato early blight disease, through (2020/2030), (2030/2040) and (2040/ 2050) in tested governorates maybe highly changed in during (2020/2030) and (2030/2040) seasons compared with seasons (2008/2018), where disease severity was $18.8 \%$ during (2008/2018) season and was $24.7 \%$ and $27.3 \%$ during (2020/2030) and (2030/2040) seasons, respectively. Also, slight changes in severity of disease through seasons (2040/2050) compared with seasons (2008/2018), where disease severity was 20.0 and $13.8 \%$, respectively at Beheira governorate. Highest changes in disease severity was estimated through seasons (2020/2030), (2030/2040) and (2040/2050) compared with seasons (2008/2018) (15.4\%), where disease severity was 30.0 , 33.5and $36.3 \%$ during (2020/2030), (2030/2040) and (2040/2050) seasons at Ismailia governorate, respectively.

Meanwhile, highest changes in severity of disease during seasons (2020/2030), (2030/2040) and (2040/ 2050) compared with seasons (2008/2018) (18.8\%), where expected disease severity are $38.1, \quad 38$ and $40.4 \%$ during (2020/2030), (2030/2040) and (2040/2050) seasons at Assuit governorate, respectively.

Climate change may have minor impact on diseases compared with the impact of crop management and genetic improvement (Kropff et al 1993). Hulme et al (2002) predicate that temperature will rise by $0.5-1.5^{\circ} \mathrm{C}$ by the 2020 s and by 2 $4^{\circ} \mathrm{C}$ by the 2080s. Warning will be great in summer than in winter and there will be an increased frequency of very hot summers, partially by the 2080s. Total annual projected to fall by up to $10 \%$ and $50 \%$ by the 2020 s and 2080 s, respectively. Abolmaaty, (2006) concluded also that there is a positive relationship between development and severity of wheat rust diseases and location, date or mean temperature, during growing seasons 2005s, under climate conditions at eight governorates in Egypt. 


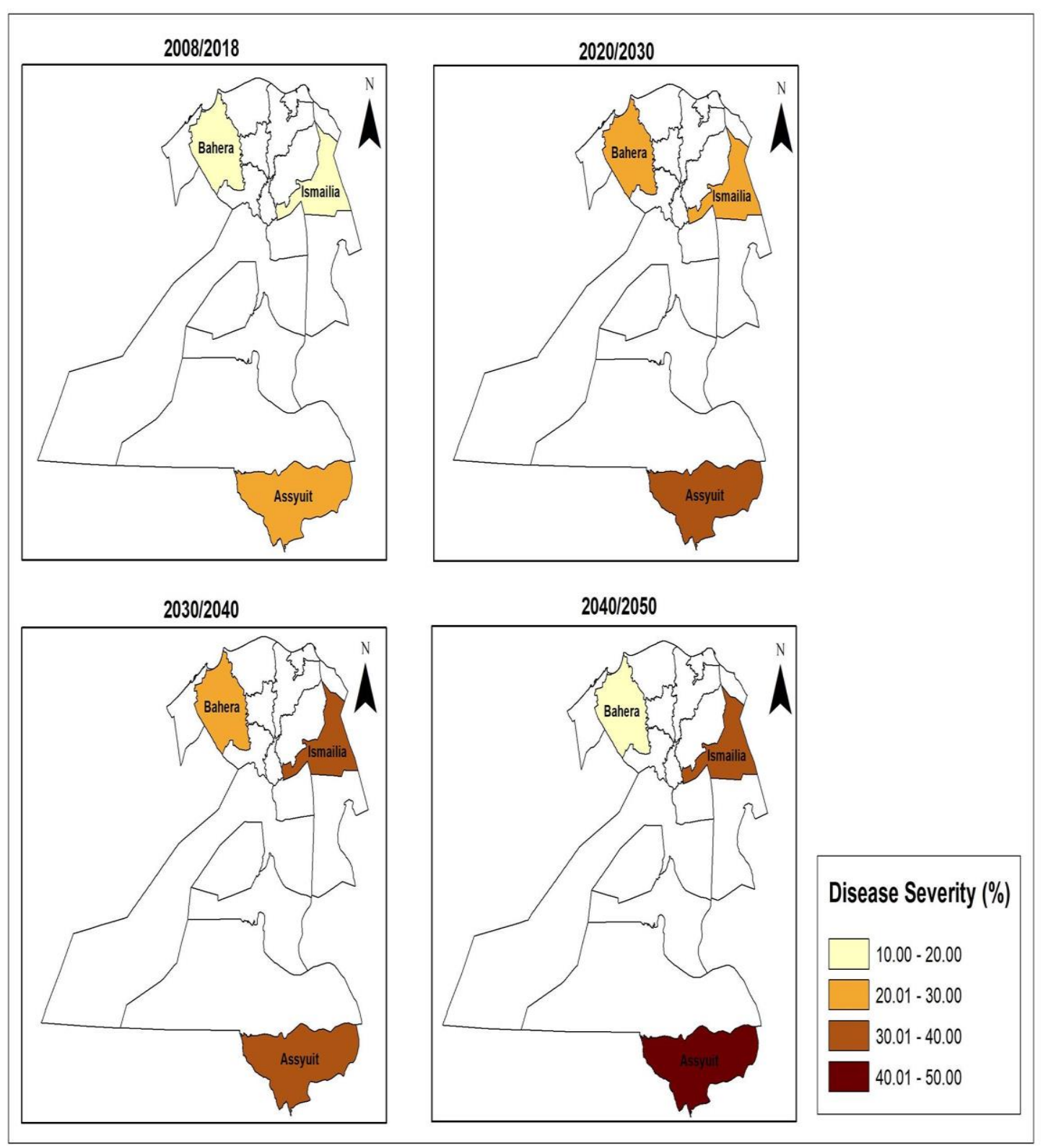

Fig. 3. Distributive maps for forecasting severity of early blight disease of tomato, under climate change in Egypt, during 2020/2030,2030/2040 and 2040/2050s growing seasons using estimated diseases severity in $2008 / 2018$ s seasons, at three different governorates 


\section{REFERENCES}

Abada K.A., Mostafa S.H. and Mervat R. 2008 Effect of some chemical salts on suppressing the infection by early blight disease of tomato. Egyptian J. of Applied Sci., 23, 47-58.

Abdel-Hak T.M., Kamal A.H., Keddis S. and Shenouieda I. 1966. Epidemology of wheat rusts in U.A.R.(Egypt). Plant Protection Dept., Cereal Diseases Research Division, Technical Bulletin, 1, 1-46.

Abolmaaty S.M. 2006. Assessment of the Impact of Climate Change on Some Rust Disease For Wheat Crop Under Egyptian Environmental Conditions. Ph.D. Thesis. Fac. Agric. AlAzhar Univ., 122 p.

Ayandiji A.O. and AdeniyiOmidiji D. 2011. Determinant post-harvest losses among tomato farmers in Imeko-Afon local government area of Ogun State, Nigeria. Glo. J. of Sci. Frontier Res., 11(5), 22-28.

Coakley S.M., Scherm H. and Chakraborty S. 1999. Climate change and disease management. Ann. Rev. Phytopathol. 37, 399-426.

Fahim M.A. 2002. Forecasting of Potato Late Blight Under the Egyptian Environmental Conditions. MS.C. Thesis. Fac. Agric. Univ. Ain Shams, $114 \mathrm{p}$.

Glala A.A., Hoda A.M. and Fawzi Z.F. 2005. Improving tomato plant growth, health, earliness, productivity and fruit quality by chemically induced systematic resistance. J. of Applied Sci. Research 1, 362-372.

Gwary D.M. and Nahunnaro H. 1998. Epiphytotics of early blight of tomatoes in Northeastern Nigeria. Crop Prot. 17(8), 619-624.

Hassan H.A. 2016. Impact of climate changes on some pests and diseases infesting faba bean plant under Egyptian conditions. M.Sc. Thesis. Fac. Agric., Ain Shams Univ., Cairo, Egypt 125 p.

Hulme M., Jenkins G.J., Lu X., Turnpenny J.R., Mitchell T.D., G. Jones R., Lowe J., Murphy J.M., Hassell D., Boorman P., McDonald R. and Hill S. 2002. Climate Change Scenarios for the United Kingdom: The UKCIP02 Scientific Report, Tyndall Centre for Climate Change Research, School of Environmental Sci., Univ. of East Anglia, Norwich, UK, 120 p.
KarIman M., Hansson P. and Witzell J. 1994. Scleroderris canker on lodgepole pine introduced in northern Sweden. Can. J. for Res., 24, 1948-1959.

Khalil A.A., Essa Y.H., Hassan H.A. and Abolmaaty S.M. 2016. Plant diseases for major crops in Egypt under future climate conditions. Int. J. of Current, 6(12), 149-154.

Kropff M.J., Cussman K.G. and Penning F.W.T. 1993. Increasing the yield plateau in rice and the role of global climate change. J. of Agric. Meteorological 48, 795-798.

Lonsdale D. and Gibbs J.N. 1996. Effects of climate change on fungal disease of trees. In Frankland, J.C., Magan, N. and Gadd, G.M. (eds.) Fungi and Environmental changeSymp. British Mycological Society, Cranfield University, U.K. March pp. 1-9.

Martens J.W., McKenzie R.I.H. and Green G.J. 1967. Thermal stability of stem rust resistance in oat seedlings. Canadian J. of Botany 45, 451-458.

MINITAB 1995. Minitab release 12.2 xtra. 3081 Enterprise Drive, State Collage, PA.

Nicholls N. 1997. Observed climate variability and change. In: Houghton, J. T., and others (eds). Climate Change 1995: The Science of Climate Change. Report of IPCC Working Group I Cambridge, Cambridge Univ. Press, pp. 137192.

Prajapati H.N., Panchal R.K. and Patel S.T. 2014. Efficacy of bioagents and biological interaction of Alternaria solani with phylloplane mycoflora of tomato. J. of Mycopathol. Res., 52, 81-86.

Prestidge R.A. and Pottinger R.P. 1990. The Impact of Climate Change on Pests, Diseases, Weeds and Bene®cial Organisms Present in New Zealand Agricultural and Horticultural Systems. MAF Technology, Ruakura Agricultural Centre, Hamilton, NZ.

Rosenzweig C., Iglesias A., Yang Y.B., Epstein P.R. and Chivian E. 2000. Climate Change and U.S. Agriculture: The Impacts of Warming and Extreme Weather Events on Productivity, Plant Diseases and Pests. Boston, MA, USA: Center for Health and the Global Environment, Harvard Medical School. 
Scherm H. and Yang X.B. 1995. Interannual variations in wheat rust development in China and the United States in relation to El Ni.o/Southern Oscillation. Phytopathol., 85, 970-976.

Sethumadhava R., Syed D., Sham K., Haben T., Rahwa T. and Tomas H. 2016. Pathological Survey on Disease Incidence and Severity of Major Diseases on Tomato and Chilli Crops Grown in Sub Zoba Hamelmalo, Eritrea. Int. J. of Research Studies in Agric. Sci. 2(1), 2031.

Sherf A.F. and MacNab A.A. 1986. Vegetable diseases and their control. John Wiley and Sons, New York. 634-640.
Strange R.N. 1993. Plant Disease Control: Towards Environmentally Acceptable Methods. London: Chapman\& Hall.

Syed D.Y.N., Awet Bereket T., Gazae A. and Ruta M. 2016. Survey on economical important fungal diseases of tomato in sub-zoba hamemalo of Eritrea. Review of Plant Studies, Conscientia Beam, 1(2), 39-48.

Wilson J.R., Deinum B. and Engels F.M. 1991. Temperature effects on anatomy and digestibility of leaf and stem of tropical and temperate forage species. Neth. J. Agric. Sci., 39, 31-48. 


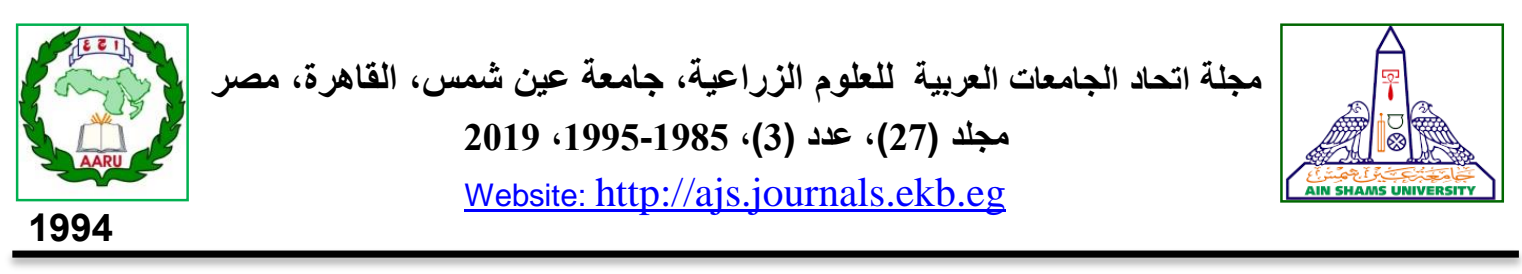

التنبؤ بمرض لفحة الطماطم المبكرة تحت ظروف تغير المناخ فى مصر

[159]

\author{
حسن أحمد حسن 1" - شاكر محمد ابو المعاطى1 1 - عفاف زين العابدين المنيسى 2 ـ \\ ناجى يسين عبد الغفار 2

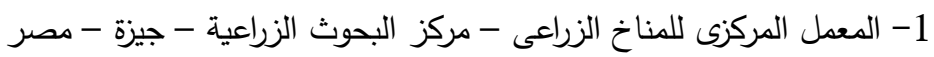

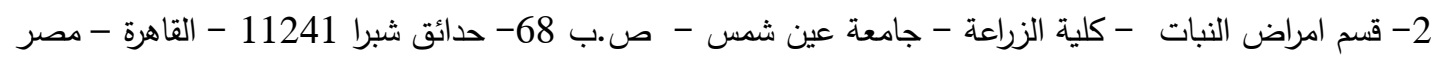 \\ *Corresponding author: Hassan clac@yahoo.com
}

Received 21 August, 2019 Accepted 4 September, 2019

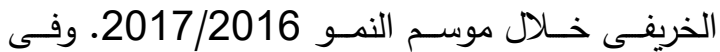

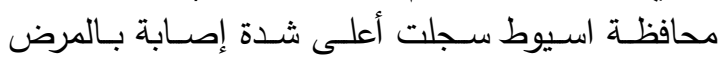

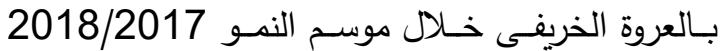
وكانت اقل شدة اصسابة كانت بالعروة الثتوية خـلال

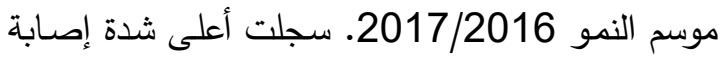

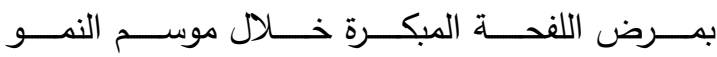
2018/2017 واقل شدة اصابة كانت فى موسم النمو دوس الفي

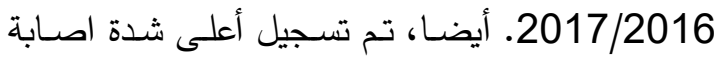

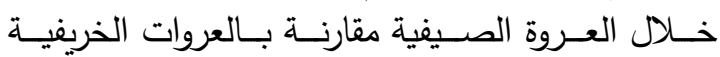
والثتوية، ولكن خلال العروة الثتوية سجلت أقل شدة التهات

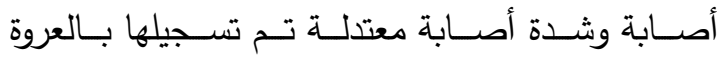

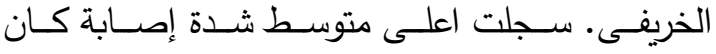

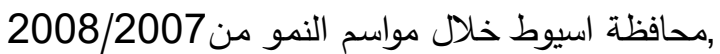

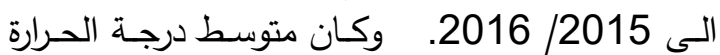

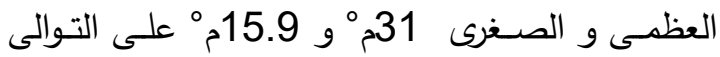

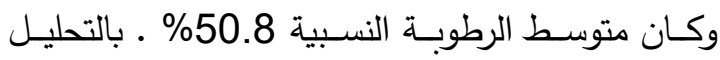
الاحصائى كان تاثير درجة الحرارة العظمى والصغنرى

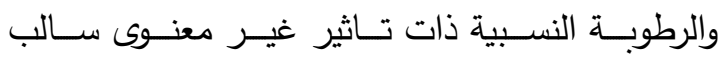
بمحافظة البحيرة وبينما بمحافظة الاسماعيلية كان تاثير

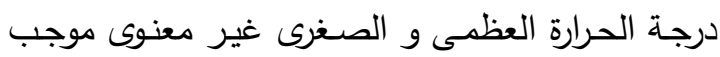
وكان تأثير متوسط الرطوبة النسبية غير معنوى موجبر منب موجب

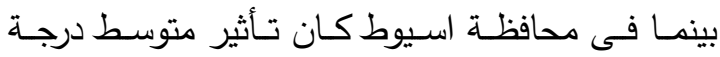

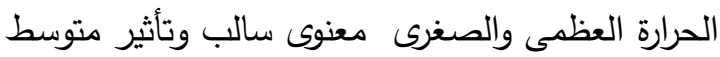

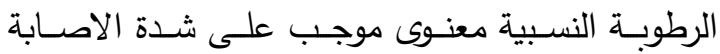

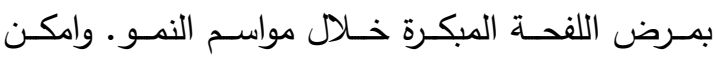

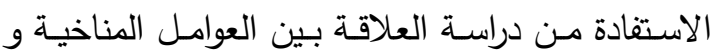

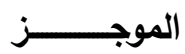

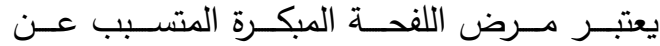

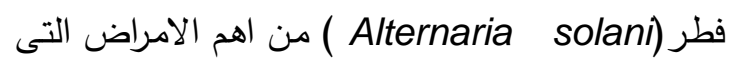

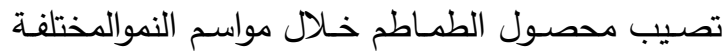

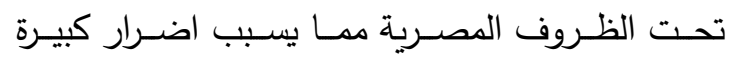

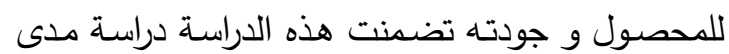

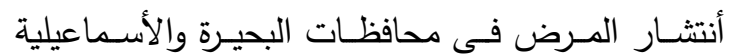

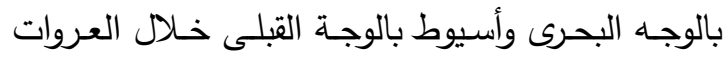

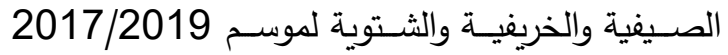

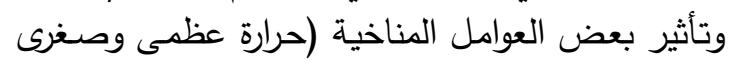

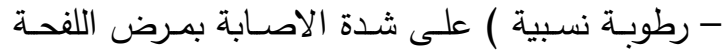
المبكرة و كذلك تم الحصول على بيانات شدة الاصدابة

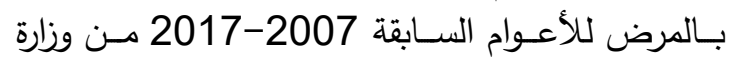

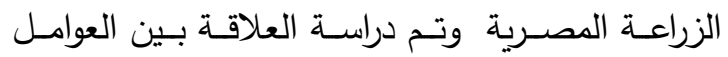

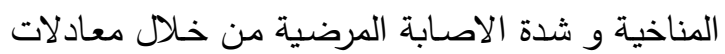

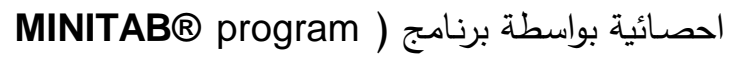
وإمكانية الاستفادة منها للتتبؤ بالمرض (for window

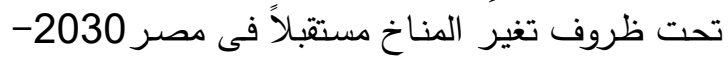

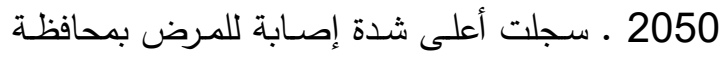

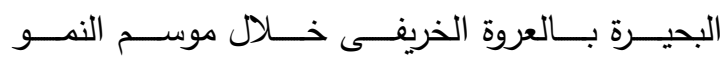

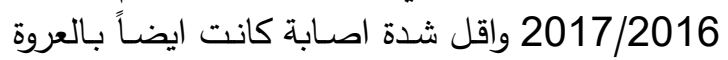

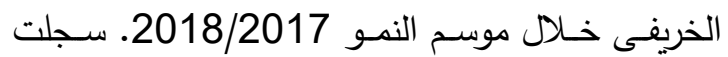

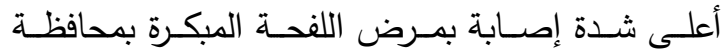

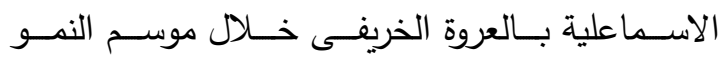

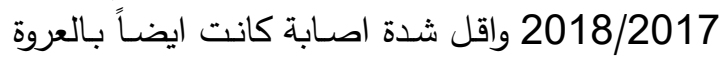




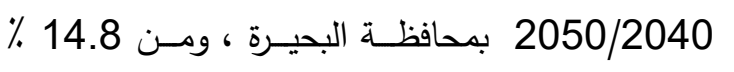

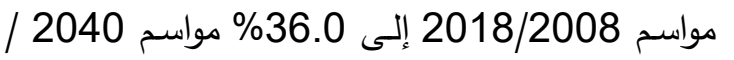

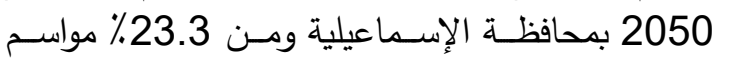

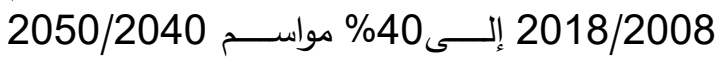
بمحافظة أسيوط مـع تغير طفيف في درجات الحرارة القصوى أو الدنيا و الرطوبة النسبية.

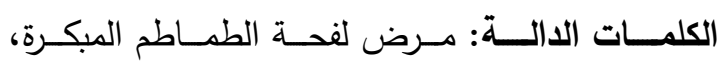

التغيرات المناخية، التتبؤ، نظم المعلومات الجغرافية

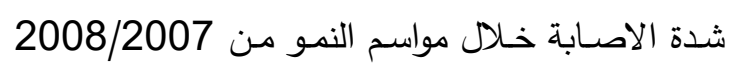
الى 2016/2015 باستخدام برنامج ) MINITABß

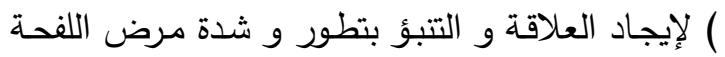

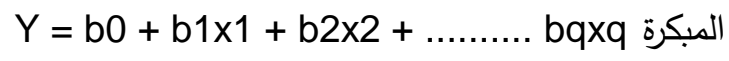

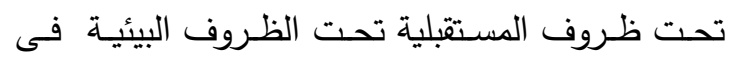
المحافظات المصرية الثلاثة .تتوقع وجود اختلاف كبير

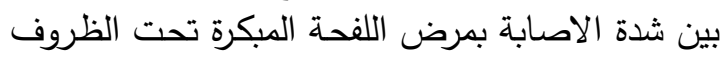

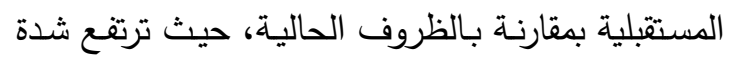

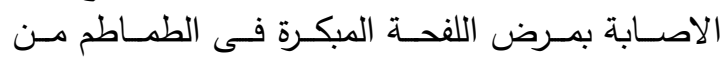

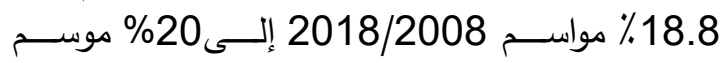

